

Original Article

\section{Perbedaan Neutrophyl Lymphocyte Ratio, Platelet Lymphocyte Ratio dan Monocyte Lymphocyte Ratio pada Pasien Diabetes Mellitus Tipe 2 dengan dan Tanpa Komplikasi Kardiovaskular}

\author{
Prihartiwi Purnamasari ${ }^{1}$, Banundari Rachmawati ${ }^{2}$ \\ ${ }^{1}$ PPDS-1 IImu Patologi Klinik, Fakultas Kedokteran Universitas Diponegoro/RSUP Dr. Kariadi, Semarang \\ ${ }^{2}$ Bagian Patologi Klinik, Fakultas Kedokteran Universitas Diponegoro/RSUP Dr. Kariadi, Semarang
}

\begin{abstract}
Abstrak
Latar belakang : Proses inflamasi memegang peranan penting dalam patogenesis diabetes mellitus (DM) tipe 2 dan mendahului timbulnya komplikasi kardiovaskular. Parameter neutrophyl lymphocyte ratio (NLR), platelet lymphocyte ratio (PLR) dan monocyte lymphocyte ratio (MLR) merupakan biomarker potensial, merefleksikan inflamasi namun belum digunakan secara rutin. Penelitian ini ingin mengetahui perbedaan NLR, PLR dan MLR pada pasien DM tipe 2 dengan dan tanpa komplikasi kardiovaskular.

Metode : Penelitian deskriptif analitik dengan pendekatan belah lintang (cross sectional) pada 30 pasien DM dan 30 pasien DM dengan komplikasi jantung pada bulan Juli - Oktober tahun 2016 di RSUP Dr. Kariadi Semarang. Subyek penelitian berusia 30-80 tahun dan sudah menderita penyakit lebih dari 5 tahun. Pasien dengan infeksi/inflamasi lain, kelainan sistem hematologi, riwayat kanker/sedang menjalani kemoterapi/radiasi dan penderita yang meminum selain obat diabetes dan obat jantung dikeluarkan dari penelitian. Analisis data dengan uji t tidak berpasangan. Signifikan jika $p<0,05$.

Hasil : Nilai NLR dan MLR pada pasien DM tipe 2 tanpa komplikasi jantung lebih rendah daripada pasien DM dengan komplikasi jantung $(2,58(0,98-4,72)$ VS $2,98(1,42-7,17) p=1,000)$ dan $(0,27$ $(0,12-0,87)$ VS $0,31(0,14-1,60), p=0,183)$. Nilai PLR pasien DM tipe 2 tanpa komplikasi jantung lebih tinggi daripada pasien DM dengan komplikasi jantung $(125,35(34,48-540,93)$ VS 121,40 (58,90-354,69), $p=0,723)$.

Simpulan : Tidak terdapat perbedaan bermakna NLR, PLR dan MLR pada pasien DM tipe 2 dengan dan tanpa komplikasi kardiovaskular.
\end{abstract}

Kata kunci : Neutrophyl lymphocyte ratio, platelet lymphocyte ratio, monocyte lymphocyte ratio, diabetes mellitus tipe 2 , komplikasi kardiovaskular.

\section{Difference of neutrophyl lymphocyte ratio, platelet lymphocyte ratio and monocyte lymphocyte ratio in type 2 diabetes mellitus patients with and without cardiovascular complication}

Abstract

Background : Inflammation process holds important role in pathogenesis of type 2 diabetes mellitus and precedes the cardiovascular complication. The neutrophyl lymphocyte ratio (NLR), platelet lymphocyte ratio (PLR) and monocyte lymphocyte ratio (MLR) parameters are potential biomarker that reflects the inflammatory process. This study aims to determine the difference between NLR, MLR and PLR in type 2 diabetes mellitus patient with and without cardiovascular complication.

Methods : This is a descriptive analytic study with cross sectional approach from July until October 2016. Type 2 diabetes mellitus patients with/without cardiac complication (30 patient in each group), aged 3080 years old, and had the disease for more than 5 years, were included in the study. Patients with sign of infection, inflammation, aberration of haematology system, history of malignancy, ongoing chemotherapy/radiotherapy procedure, and on going medication other than diabetes or cardiac drugs were excluded from this study. Data analysis being performed with unpaired t test. The value of significance was $p<0.05$.

Results : The value of NLR and MLR in diabetes mellitus patient without cardiac complication were lower than diabetes mellitus patient with cardiac complication $(2.58(0.98-14.72)$ vs. 2.98 $(1.42-7.17) p=1.000)$ and $(0.27(0.12-0.87)$ vs. $0.31(0.14-1.60)$, $p=0.183)$. The value of PLR in diabetes mellitus patient without cardiac complication was higher than diabetes mellitus patient with cardiac complication (125.35 (34.48-540.93) vs. 121.40 (58.90-354.69), $p=0.723$ ). 
Conclusion : There was no significant difference between NLR, $P L R$, and MLR parameters in type 2 diabetes mellitus patients with and without cardiovascular complication.

Keywords : Neutrophil lymphocyte ratio, platelet lymphocyte ratio, monocyte lymphocyte ratio, type 2 diabetes mellitus, cardiovascular complication.

\section{PENDAHULUAN}

DM tipe 2 merupakan salah satu penyakit kronis yang banyak terjadi di dunia dan menjadi penyebab utama dalam perkembangan penyakit kardiovaskular. Indonesia menempati urutan ke 7 di dunia sebagai negara dengan penderita diabetes tertinggi setelah China, India, Amerika Serikat, Brazil, Rusia, dan Meksiko pada tahun 2015. ${ }^{1}$ Prevalensi orang dengan diabetes di Indonesia cenderung meningkat berdasarkan data dari Riset Kesehatan Dasar (Riskesdas) yaitu dari 5,7\% pada tahun 2007 menjadi 6,9\% pada tahun $2013 .^{2}$

Proses inflamasi memegang peranan penting dalam patogenesis DM tipe 2 dan mendahului timbulnya berbagai penyakit termasuk komplikasi vaskular diabetik. ${ }^{3}$ Komplikasi diabetes menjadi penyebab kematian ketiga di Indonesia. ${ }^{4}$ Coronary artery disease (CAD) merupakan salah satu komplikasi kardiovaskular dari diabetes. ${ }^{1}$ Jumlah lekosit dan subtipenya merupakan indikator inflamasi yang klasik. Neutrophyl lymphocyte ratio (NLR) adalah rasio antara jumlah netrofil absolut dan jumlah limfosit absolut, platelet lymphocyte ratio (PLR) adalah rasio antara jumlah platelet dan jumlah limfosit absolut, sedangkan monocyte lymphocyte ratio (MLR) adalah rasio antara jumlah monosit absolut dan jumlah limfosit absolut. Ketiga parameter ini merupakan biomarker potensial yang merefleksikan inflamasi dan respon imun pada berbagai kondisi medis meliputi tumor, ${ }^{5-7}$ kondisi kardiovaskular ${ }^{8,9}$ dan penyakit lainnya. ${ }^{10}$ NLR dan PLR baru baru ini diselidiki sebagai prediktor baru untuk mengetahui outcome kardiovaskular yang buruk. ${ }^{11}$ Penelitian lain oleh Ibrahim Sarl, dkk juga menyimpulkan bahwa NLR dan PLR merupakan metode sederhana untuk memprediksi derajat CAD pada pasien yang akan menjalani coronary angiography (CAG). ${ }^{12}$ Penelitian mengenai MLR belum banyak dilakukan. Salah satu penelitian mengenai MLR adalah pada penderita diabetes retinopati, dimana MLR digunakan untuk memprediksi kejadian diabetes retinopati. ${ }^{13}$ Ketiga parameter hematologi ini merupakan parameter yang murah dan mudah untuk dilakukan karena hasil pemeriksaannya dapat langsung keluar secara otomatis dari alat hematologi analyzer.

Tujuan penelitian ini untuk mengetahui bagaimana perbedaan masing masing pe tanda inflamasi hematologi tersebut pada pasien diabetes mellitus tipe 2 dengan dan tanpa komplikasi kardiovaskular.

\section{METODE}

Penelitian ini merupakan penelitian deskriptif analitik dengan pendekatan belah lintang (cross sectional). Pengambilan sampel dilakukan secara consecutive sampling yang melibatkan 60 pasien, terdiri dari 37 orang laki-laki dan 23 orang perempuan. Sampel penelitian adalah penderita diabetes mellitus tipe 2 tanpa komplikasi kardiovaskular dan penderita diabetes mellitus tipe 2 dengan komplikasi kardiovaskular yang datang ke RSUP Dr. Kariadi Semarang dan bersedia ikut dalam penelitian untuk dilakukan pemeriksaan darah serta memenuhi kriteria antara lain berusia 30-80 tahun, sudah menderita diabetes lebih dari 5 tahun pada kedua kelompok. Diagnosis komplikasi kardiovaskular ditegakkan oleh dokter klinisi jantung. Pasien yang sedang mengalami infeksi aktif atau inflamasi lain, penderita kelainan sistem hematologi, penderita dengan riwayat kanker atau sedang menjalani kemoterapi / radiasi, penderita dengan penyakit ginjal dan penderita yang meminum obat selain obat diabetes dan obat jantung dikeluarkan dari penelitian. Penelitian dilakukan pada periode bulan Agustus 2016 dan sudah mendapatkan persetujuan dari komisi etik penelitian kesehatan fakultas kedokteran UNDIP / RSUP Dr. Kariadi Semarang No. 761/EC/FK-RSDK/2016

Hematologi rutin diperiksa menggunakan alat hematology analyzer Cell Dyne Saphire untuk mengetahui kondisi hematologi pasien, subtipe lekosit dan menghitung rasio inflamasi hematologi. Jumlah lekosit pada masing-masing populasi penelitian berada dalam rentang rujukan normal yaitu 4-11 x 109/L. Penelitian ini menggunakan pasien dengan kadar lekosit normal guna menyingkirkan adanya inflamasi atau infeksi lain yang sedang terjadi. GDP, GD 2 PP dan HbA1c diperiksa untuk menegakkan diagnosis DM tipe 2 dan untuk mengetahui kontrol glukosa pasien. Pemeriksaan kadar kreatinin darah dilakukan untuk menyingkirkan kemungkinan telah terjadinya gagal ginjal kronik yang dapat menyebabkan peningkatan petanda inflamasi.

Data diolah menggunakan program komputer. Normalitas data dilakukan dengan uji Shapiro-Wilk. Analisis data menggunakan uji $t$ tidak berpasangan. Signifikansi dinyatakan pada $p<0,05$. 


\section{HASIL}

Subyek penelitian sejumlah 60 pasien terdiri atas 30 pasien diabetes mellitus tanpa komplikasi jantung dan 30 pasien diabetes mellitus dengan komplikasi jantung. Diagnosis jantung pada penelitian ini meliputi 18 pasien dengan chronic heart failure (CHF), 6 pasien dengan ischemic heart disease (IHD), 4 pasien dengan acute miocard infark (AMI) dan 1 pasien dengan unstable angina pectoris (UAP). Data mengenai karateristik subjek penelitian dapat dilihat pada tabel 1 .
Pasien diabetes dengan komplikasi jantung menunjukkan usia yang lebih tua, indeks massa tubuh yang lebih tinggi, tekanan darah sistole yang lebih tinggi, dan menderita DM yang lebih lama dibandingkan dengan pasien DM tanpa komplikasi jantung. Pasien DM dengan komplikasi jantung juga memiliki riwayat merokok yang signifikan secara statistik dibandingkan pasien yang belum mendapat komplikasi jantung. Berdasarkan jenis kelamin dari masing-masing populasi penelitian ditemukan bahwa laki-laki lebih lebih banyak menderita penyakit.

\begin{tabular}{|c|c|c|c|}
\hline \multirow[t]{2}{*}{ Parameter } & \multicolumn{2}{|c|}{ Diagnosis } & \multirow[t]{2}{*}{$p$} \\
\hline & $\begin{array}{c}D M \\
(n=30)\end{array}$ & $\begin{array}{c}\text { DM+ Jantung } \\
(n=30)\end{array}$ & \\
\hline Usia (tahun) & $52(41-74)$ & $58,5(43-80)$ & $0,003^{* \S}$ \\
\hline Jenis kelamin (Pria/\%) & $17(56,7)$ & $18(60,0)$ & $0,793^{¥}$ \\
\hline $\mathrm{IMT}\left(\mathrm{kg} / \mathrm{m}^{2}\right)$ & $22,68(18,9-25,15)$ & $26,14(22,3-28,76)$ & $<0,001^{* \S}$ \\
\hline TDS (mmHg) & $120(120-140)$ & $140(120-160)$ & $<0,001^{* \S}$ \\
\hline TDD (mmHg) & $80(70-90)$ & $80(60-90)$ & $0,749^{\S}$ \\
\hline Lama DM (tahun) & $5(5-15)$ & $9(5-20)$ & $<0,001^{* \S}$ \\
\hline Merokok (Ya/\%) & $7(23,3)$ & $16(53,3)$ & $0,017^{*} ¥$ \\
\hline
\end{tabular}

Keterangan : IMT : Indeks Massa Tubuh, TDS : Tekanan Darah Sistole, TDD : Tekanan Darah Diastole * Signifikan $p<0,05$;

$¥$ Chi Square; § Mann-Whitney

\section{TABEL 2}

\section{Perbedaan pemeriksaan parameter laboratorium 2 kelompok populasi penelitian}

\begin{tabular}{|c|c|c|c|}
\hline \multirow{2}{*}{$\begin{array}{l}\text { Parameter } \\
\text { Laboratorium }\end{array}$} & \multicolumn{2}{|c|}{ Diagnosis } & \multirow[t]{2}{*}{$p$} \\
\hline & $\begin{array}{c}D M \\
(n=30)\end{array}$ & $\begin{array}{c}\text { DM + Jantung } \\
(\mathbf{n}=30)\end{array}$ & \\
\hline GDP (mmol/L) & $183,53 \pm 77,39$ & $151,33 \pm 45,31$ & $0,055^{\text {थ }}$ \\
\hline GD2PP (mmol/L) & $246(107-582)$ & $186(101-361)$ & $0,007^{* \S}$ \\
\hline HbA1c (\%) & $9,95(6,7-13,3)$ & $8,00(6,1-16,1)$ & $0,048^{\S}$ \\
\hline $\mathrm{Hb}(\mathrm{gr} / \mathrm{dl})$ & $12,91 \pm 1,54$ & $13,36 \pm 2,12$ & $0,342^{\pi}$ \\
\hline Leukosit (x109/L) & $9(5,01-11,0)$ & $9,09(6,06-10,9)$ & $0,894^{\S}$ \\
\hline Netrofil (x109/L) & $6,05+1,99$ & $5,85+1,45$ & $0,655^{\text {ๆ }}$ \\
\hline Limfosit (x109/L) & $1,92+0,80$ & $1,98+0,67$ & $0,716^{\text {थ }}$ \\
\hline Monosit (x109/L) & $0,55(0,22-0,91)$ & $0,66(0,30-1,57)$ & $0,018^{* \S}$ \\
\hline Platelet $\left(\times 10^{9} / \mathrm{L}\right)$ & $251,17 \pm 82,04$ & $250,2 \pm 74,65$ & $0,962^{\text {था }}$ \\
\hline Creatinin (mg/dl) & $1,1 \pm 0,38$ & $1,22 \pm 0,36$ & 0,236 ๆ \\
\hline
\end{tabular}

Keterangan : GDP : Gula Darah Puasa, GD2PP : Gula Darah 2 Jam Post Prandial, HbA1c : Hemoglobin terglikasi, Hb : Hemoglobin

*Signifikan $p<0,05$; § Mann Whitney; १ Uji t 
TABEL 3

Analisis perbedaan parameter inflamasi pada pasien DM Tipe 2 dengan dan tanpa komplikasi kardiovaskular

\begin{tabular}{|c|c|c|c|}
\hline \multirow{2}{*}{$\begin{array}{l}\text { Parameter } \\
\text { Hematologi }\end{array}$} & \multicolumn{2}{|c|}{ Diagnosis } & \multirow[t]{2}{*}{$p$} \\
\hline & $\begin{array}{c}D M \\
(n=30)\end{array}$ & $\begin{array}{c}\text { DM + Jantung } \\
(\mathrm{n}=30)\end{array}$ & \\
\hline NLR & $2,58(0,98-14,72)$ & $2,98(1,42-7,17)$ & $1,000^{\S}$ \\
\hline MLR & $0,27(0,12-0,87)$ & $0,31(0,14-1,60)$ & $0,183^{\S}$ \\
\hline PLR & $125,35(34,48-540,93)$ & $121,40(58,90-354,69)$ & $0,723^{\S}$ \\
\hline
\end{tabular}

Keterangan : NLR : neutrophyl lymphocyte ratio; PLR : platelet lymphocyte ratio, MLR : monocyte lymphocyte ratio

* Signifikan $p<0,05$; § Mann Whitney

Berdasarkan tabel 2 ditemukan kadar GDP, GD2PP dan HbA1c yang lebih tinggi pada pasien DM tanpa komplikasi jantung dibandingkan pasien DM yang telah mengalami komplikasi jantung.

Berdasarkan tabel 3 terlihat bahwa nilai NLR dan MLR pada pasien DM tanpa komplikasi jantung lebih rendah daripada pasien DM dengan komplikasi jantung. Nilai PLR pada pasien DM tanpa komplikasi jantung lebih tinggi daripada nilai PLR pasien DM dengan komplikasijantung.

\section{DISKUSI}

Proses inflamasi memegang peranan penting dalam patogenesis DM tipe 2 dan mendahului timbulnya berbagai penyakit. Inflamasi subklinis berkontribusi memperberat gangguan metabolik, selanjutnya akan berkembang menjadi komplikasi vaskular diabetik serta menjadi penyebab utama morbiditas dan mortalitas pada pasien diabetes. ${ }^{3}$ Peningkatan kadar inflamasi dihubungkan dengan prognosis yang buruk pada pasien jantung. Reaksi inflamasi memegang peranan penting dalam perkembangan terjadinya gagal jantung pada pasien diabetes. ${ }^{12}$

Lekosit dan subtipenya merupakan petanda inflamasi yang bagus untuk penyakit jantung. Lekosit akan mengeluarkan banyak sitokin inflamasi seperti TNF-a, IL-6 dan CRP sebagai enzim proteolitik pada kondisi inflamasi. Sitokin-sitokin pro inflamasi ini memiliki efek merusak pada miokardium dan dapat menyebabkan terjadinya gagal jantung. Selain lekosit dan subtipenya, nilai NLR, MLR dan PLR merupakan biomarker yang potensial dalam merefleksikan inflamasi dan respon imun. ${ }^{13}$

Data demografi penelitian ini menunjukkan adanya perbedaan yang bermakna pada parameter usia, indeks massa tubuh, tekanan darah sistole, lama DM dan riwayat merokok. Semua parameter tersebut lebih tinggi pada pasien DM dengan komplikasi jantung. Faktorfaktor tersebut mungkin menjadi faktor predisposisi berkembangnya penyakit DM menjadi DM dengan komplikasi jantung. Nilai PLR pada pasien DM dengan komplikasi jantung lebih rendah daripada pasien DM tanpa komplikasi jantung. Nilai NLR dan MLR pada pasien DM dengan komplikasi jantung lebih tinggi daripada pasien DM tanpa komplikasi jantung. Hal ini berbeda dengan hasil penelitian sebelumnya oleh Dumus, dkk (2015) pada populasi gagal jantung dan kontrol sehat, menunjukkan bahwa pasien dengan gagal jantung memiliki nilai PLR dan NLR yang lebih tinggi dibandingkan dengan kontrol sehat. ${ }^{14}$ Penelitian ini didapatkan jumlah platelet pada pasien DM dengan komplikasi jantung lebih rendah daripada jumlah platelet pada pasien DM tanpa komplikasi jantung. Rendahnya nilai PLR pada pasien DM dengan komplikasi jantung dapat disebabkan karena pasien dengan komplikasi jantung yang sudah lama seperti halnya CHF biasanya mengkonsumsi obat-obatan seperti acetil asam salisilat / aspirin yang memiliki efek menurunkan jumlah trombosit. ${ }^{15} \mathrm{Hal}$ ini sesuai dengan penelitian oleh Yue S, dkk (2015), menyatakan bahwa pasien DM dengan retinopati diabetes memiliki nilai NLR yang lebih tinggi daripada pasien DM tanpa retinopati diabetes. ${ }^{16}$

Monosit dipertimbangkan sebagai biomarker inflamasi karena aktivitas dari monosit menyebabkan terjadinya sintesis sitokin inflamasi. Laporan sebelumnya menyebutkan bahwa monosit mungkin relevan dalam proses angiogenic pada aterosklerosis. ${ }^{17}$ Penelitian ini menemukan perbedaan bermakna pada jumlah monosit yang beredar di peredaran darah. Pasien DM dengan komplikasi jantung memiliki jumlah monosit yang lebih banyak daripada pasien DM tanpa komplikasi. Hal ini sejalan dengan nilai MLR pada pasien DM dengan komplikasi jantung lebih tinggi daripada pasien DM tanpa komplikasi. Hasil ini menunjukkan bahwa pasien DM yang sudah mengalami komplikasi jantung merupakan pasien yang mengalami inflamasi kronis tahap lanjut. Hasil penelitian ini didapatkan pasien dengan komplikasi jantung memiliki kadar glukosa puasa, glukosa 2 jam PP dan kadar HbA1c lebih rendah dibandingkan pasien tanpa komplikasi jantung. 
Hal ini diduga karena pasien DM yang sudah mengalami komplikasi jantung memiliki kesadaran untuk lebih menjaga pola makan dan keteraturan dalam meminum obat-obatan dibandingkan pasien DM yang belum mengalami komplikasi.

Penelitian ini tidak menemukan perbedaan bermakna pada marker hematologi inflamasi antara kedua kelompok penelitian, namun tidak berarti bahwa inflamasi bukan sebagai penyebab berkembangnya komplikasi kardiovaskular pada pasien diabetes. Keterbatasan pada penelitian ini, konsumsi obat-obatan rutin pada beberapa subyek tidak tercatat. Kondisi tersebut kemungkinan dapat mempengaruhi hasil penelitian.

\section{SIMPULAN}

Tidak terdapat perbedaan bermakna pada parameter NLR, MLR dan PLR antara pasien DM dengan pasien DM yang disertai komplikasi jantung. Pasien dengan komplikasi jantung cenderung usianya lebih tua, memiliki indeks massa tubuh dan tekanan darah sistole yang lebih tinggi, menderita diabetes lebih lama dan memiliki riwayat merokok daripada pasien tanpa komplikasijantung.

Pasien diabetes dengan komplikasi jantung cenderung memiliki pola hidup yang lebih sehat. Ditemukan kadar gula dan kadar kontrol glikemik HbA1c yang lebih rendah secara bermakna pada pasien diabetes dengan komplikasi jantung daripada pasien dengan diabetes tanpa komplikasi jantung.

\section{DAFTAR PUSTAKA}

1. International Diabetes Federation. Diabetes Atlas Seven Edition. IDF. 2015.

2. Badan Penelitian dan Pengembangan Kesehatan, Kementerian Kesehatan Republik Indonesia. Riset Kesehatan Dasar. Jakarta. 2013.

3. Wiza DP, Ziolkiewicz DZ, Wysocki H, Wysocka BW. Increase in glycemia stimulates Reactive Oxygen Species (ROS) production by polymorphonuclear neutrophils in type 2 diabetic patients. JPCCR. 2011;5(1):22-27.

4. Kementerian Kesehatan Republik Indonesia. Indonesia Sample Registration System - Deaths. 2014.

5. Gunduz S, Mutlu H, Tural D, Yıldiz O, Uysal M, Cosku HS, et al. Platelet to lymphocyte ratio as a new prognostic for patients with metastatic renal cell cancer. Asia Pac J Clin Oncol. 2015Dec;11(4):288-92.
6. Ozaksit G, Tokmak A, Kalkan H, Yesilyurt H. Value of the platelet to lymphocyte ratio in the diagnosis of ovarian neoplasms in adolescents. Asian Pac J Cancer Prev. 2015;16(5): 2037-41.

7. Liu J, Du J, Fan J, Liu K, Zhang B, Wang S, et al. The neutrophilto-lymphocyte ratio correlates with age in patients with papillary thyroid carcinoma. ORL J. Otorhinolaryngol Relat Spec. 2015;77:109-16.

8. Akyel A, Yayla C, Erat M, Çimen, T, Dogan M, Acıkel S, et al. Neutrophil-to-lymphocyte ratio predicts hemodynamic significance of coronary artery stenosis. Anatol J Cardiol. 2015; 15(12): 1002-07

9. Oylumlu M, Yıldiz A, Oylumlu M, Yuksel M, Polat N, Bilik MZ, et al. Platelet-to-lymphocyte ratio is a predictor of in-hospital mortality patients with acute coronary syndrome. Anatol J Cardiol. 2015; 15(4): 277-83

10. Warimwe GM, Fletcher HA, Olotu A, Agnandji ST, Hill AV, Marsh K, et al. Peripheral blood monocyte-to-lymphocyte ratio at study enrollment predicts efficacy of the RTS, S malaria vaccine: Analysis of pooled phase II clinical trial data. BMC Med. 2013;21:184.

11. Sunbul M, Gerin F, Durmus E, Kivrak T, Sari I, Tigen K, et al. Neutrophil to lymphocyte and platelet to lymphocyte ratio in patients with dipper versus non-dipper hypertension. Clin Exp Hypertens. 2014;36(4): 217-21.

12. Sarl I, Sunbul M, Mammadov, Durmus E, Bozbay M, Kivrak T, et al. Relation of neutrophil-to-lymphocyte and platelet-tolymphocyte ratio with coronaryartery disease severity in patients undergoing coronary angiography. Kardiol Pol. 2015; 73(12): 1310-16.

13. Kruk M, Przyłuski J, Kalińczuk Ł, Pregowski J, Deptuch T, Kadziela J, et al. Association of non-specific inflammatory activation with early mortality in patients with ST-elevation acute coronary syndrome treated with primary angioplasty. Circ J. 2008 Feb;72(2):205-11.

14. Durmus E, Kivrak T, Gerin F, Sunbul M, Sari I, Erdogan O. Neutrophil-to-Lymphocyte Ratio and Platelet-to-Lymphocyte Ratio are Predictors of Heart Failure. Arq Bras Cardiol. 2015 Dec;105(6):606-13.

15. Erhart S, Beer JH, Reinhart WH. Influence of aspirin on platelet count and volume in humans. Acta Haematol. 1999;101(3):140-4.

16. Yue S, Zhang J, Wu J, Teng W, Liu L, Chen L. Use of the Monocyte-to-Lymphocyte Ratio to Predict Diabetic Retinopathy. Ojo O, ed. Int J Environ Res Public Health. 2015 Aug;12(8):10009-19.

17. Jaipersad AS, Lip GY, Silverman S, Shantsila E. The role of monocytes in angiogenesis and atherosclerosis. J Am Coll Cardiol. 2014 Jan;63(1), 111. 